\title{
PERSPECTIVE
}

\section{Retinopathy of prematurity: recent advances in our understanding}

\section{M Wheatley, J L Dickinson, D A Mackey, J E Craig, M M Sale}

Retinopathy of prematurity (ROP) has been recognised as an important cause of childhood visual impairment and blindness since the 1940s when improved facilities and treatment increased the survival rate of premature infants. Although its incidence and severity have been decreasing in developed countries over the past two decades, both are increasing in developing nations. $\mathrm{ROP}$ is consequently targeted as an important but avoidable disease. This review provides an updated summary and discussion of much of the work that has been produced through population, animal, cell culture, and genetic research. The authors examine the prevalence, risk factors, and possible causes of the disease with a particular focus on genetic studies. They conclude that while significant reductions in the disease have occurred in developed countries, further research is required to fully understand and prevent the disease. In the meantime, development and implementation of appropriate screening and treatment strategies will be critical in reducing blindness in developing countries.

See end of article for authors' affiliations

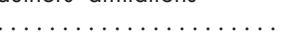

Correspondence to: Michèle Sale, PhD, Menzies Centre for Population Health Research, University of Tasmania, GPO Box 252-23, Hobart, Tasmania 7001, Australia; Michele.Sale@utas.edu.au

Accepted for publication 15 February 2002
$\mathrm{R}$ etinopathy of prematurity (ROP) is a vasoproliferative disorder of the eye affecting premature neonates. In its more severe forms, it results in severe visual impairment or blindness, both of which carry a high financial cost for the community but also a high individual cost by affecting the normal motor, language, conceptual, and social development of the child, ${ }^{12}$ which are amplified when the child commences formal education. ${ }^{13-5}$

The International Classification of $\mathrm{ROP}^{6}$ describes the location relative to the optic nerve, the extent of the developing vasculature, and the progressive staging of the disease. Stage 1 is the least severe, with stages 4 and 5 referring to partial and total retinal detachment respectively. The term "plus" disease indicates signs of ongoing ROP activity that can accompany any stage of ROP. "Threshold" ROP describes 5 contiguous or 8 cumulative clock hours of stage 3 ROP in zones I or II in the presence of "plus" disease, indicating an increased likelihood of progression to retinal detachment.

The Global Initiative for the Elimination of Avoidable Blindness ${ }^{7}$ targets ROP for prevention and treatment in an effort to reduce the prevalence of childhood blindness. In addition the World Health Organization's "Vision 2020 programme ${ }^{\prime 8}$ has identified ROP as an important cause of blindness in both high and middle income countries. In the United States, ROP remains the second most common cause of childhood blindness. ${ }^{9}$

Although the prevalence of childhood blindness is very high in countries with an infant mortality rate (IMR) greater than 60 per 1000 live births such as sub-Saharan Africa, very little or no ROP is recorded in these countries owing to the lack of intensive care facilities for premature infants and their low survival rates. In industrialised countries with IMRs of less than 10 per 1000 live births, ROP accounts for between $6-20 \%$ of childhood blindness. ${ }^{910}$ However, in countries with IMRs between 10-60 per 1000 live births, ROP is now emerging as a major cause of childhood blindness. ${ }^{10}$ The proportion of blindness caused by ROP may be underestimated in countries with a high incidence of intellectual disability (up to $75 \%{ }^{11}$ ) among blind children. Variations in incidence may also occur between areas within the same country depending on the level of available postnatal care..$^{12} 13$

In developed countries, ROP has been characterised by two notable epidemics over the past 60 years. Severe ROP (initially termed "retrolental fibroplasia" or RLF) was first described during an epidemic of the disease in the 1940s. ${ }^{14}$ In 1951, Campbell suggested that the toxic effects of uncontrolled supplemental oxygen to newborns were responsible for the epidemic. ${ }^{15}$ She emphasised the importance of maintaining pregnancies beyond the 33rd week and avoiding the use of prophylactic oxygen therapy, advocating its use only in the treatment of cyanosis. ${ }^{15}$ Subsequent studies in the same decade confirmed that high levels of oxygen obliterated blood vessels in the neonatal retina. ${ }^{16}{ }^{17}$ This epidemic ceased following controlled oxygen administration. In the United States alone, the proportion of blindness due to RLF fell from $50 \%$ in 1950 to $4 \%$ by $1965 .^{18}$ Unfortunately, this decline was accompanied by an increase in neonatal deaths from atelectasis and respiratory distress secondary to hyaline membrane disease. ${ }^{19}$

During the late 1970s and 1980s, reports emerged of a second epidemic of ROP $^{20}{ }^{21}$ similar in size to the first despite the careful monitoring of oxygen delivery to neonates since the 1950s. It was concluded that this epidemic was due to increased survival rates of very low birthweight premature infants weighing 750-999 $\mathrm{g}$ and not to new iatrogenic factors. ${ }^{21-23}$ Survival rates for premature infants less than 27 weeks' gestation continued to improve in the 1990s and, while some studies showed greater occurrence of more severe $\mathrm{ROP}^{24}$ more recent reports indicate a 
decline in incidence, severity, and progression to threshold disease in developed countries. ${ }^{25-29}$ However, ROP remains prevalent in very low birthweight infants, with as many as $12.5 \%$ of infants born between 23 and 26 weeks' gestation requiring treatment for threshold disease. ${ }^{30}$

\section{PREDISPOSING FACTORS \\ Gestational age and birth weight}

Although many causative factors have been proposed for ROP, only low birth weight, low gestational age, and supplemental oxygen therapy following delivery have been consistently associated with disease. ${ }^{31-33}$ A multicentre US study of infants born in 1986-7 reported that of those infants weighing less than $1000 \mathrm{~g}, 81.6 \%$ developed ROP, while $46.9 \%$ of those 1000-1250 g developed the disorder. ${ }^{34}$ Severe disease is seen especially in babies under 26 weeks' gestation ${ }^{35}$ with severity increasing with decreasing gestational age. ${ }^{36}$

\section{Oxygen saturation levels}

Since the link between supplemental oxygen and ROP was established, ${ }^{15}$ there has been intensive research into the role of oxygen in the pathogenesis of this condition. ROP begins to develop between 32 and 34 weeks after conception, regardless of gestational age at delivery, ${ }^{37}$ and has two distinct phases. During the acute first phase, the normal vasculogenesis of the retina is disturbed by the relative hyperoxia of the extrauterine environment. This causes vaso-obliteration and nonvascularisation of some areas of the anterior retina. ${ }^{38}$ The subsequent hypoxia causes a second chronic phase, characterised by the proliferation of vascular and glial cells, arteriovenous shunt formation, occasionally leading to involution or permanent cicatricial changes and visual impairment. ${ }^{39-41}$

Controversy surrounds whether or not the length of time over which oxygen is administered affects either the incidence or the severity of the disease. Evidence presented in a recent study demonstrates that continued provision of supplemental oxygen to infants who have developed moderate ROP does not reduce the incidence of progression to threshold disease $\mathrm{e}^{42}$ although it appears that wide fluctuations in oxygen saturation levels may affect ROP development and progression. ${ }^{43}$ In the rat model both hypoxia and unstable oxygen levels are important causes of ischaemic retinopathy. ${ }^{44}$

The significance of oxygen levels lies in the nature of the choroidal circulation which is unique in that it fails to autoregulate in response to altered oxygen tension. Under hyperoxic conditions, the choroidal vessels cannot constrict although the retinal vessels have this ability. As a result, excess oxygen moves from the choroidal to the retinal circulation, bathing the retina and constricting the retinal vessels to the point of obliteration. ${ }^{45}$

An alternative theory is that damage by reactive oxygen species may outweigh the available defence mechanisms in the form of antioxidant enzymes, particularly superoxide dismutase $^{46}$ and protective antioxidants such as $\alpha$-tocopherol. ${ }^{47}$ Hyperoxic conditions may also interfere with the growth and maturation of spindle cells, causing gap junction formation between cells and disruption of normal migration and vasculogenesis. ${ }^{48}$

Experiments with animal models, ${ }^{49-51}$ transgenic mouse models, ${ }^{52}$ non-human primates, ${ }^{53}$ and cell cultures have confirmed that the cytokine vascular endothelial growth factor A (VEGF-A) is instrumental in the development of abnormal retinal vasculature. Elevated levels of VEGF-A have been found in the vitreous of humans with $\mathrm{ROP}^{54}$ and in the subretinal fluid of eyes affected by active stage 4 but not stage 5 ROP. ${ }^{55}$ However, VEGF-A mRNA is not seen in the fetal retina until 20 weeks' gestation, implying that factors other than hypoxia may also drive VEGF-A expression. ${ }^{56}$ In support of this, insulin-like growth factor 1 (IGF-1) has recently been found to optimise the activity of VEGF-A, and lack of IGF-1 in knockout mice prevents normal retinal vascularisation. ${ }^{57}$ Studies in premature infants also suggest that persistently low serum levels of IGF-1 are a significant factor contributing to the development of $\mathrm{ROP}^{57}$ and Hellstrom et al ${ }^{57}$ propose that normalisation of IGF-1 levels may prevent ROP.

\section{Genetic factors}

ROP may develop in premature infants who have received little or no supplemental oxygen, and it is not known what determines which infants progress to retinal detachment. The hypothesis put forward in the early 1990s that genetic factors may contribute to the development of $\mathrm{ROP}^{37}$ is supported by the variation observed between ethnic groups. Although no racial correlation was identified in a study involving Chinese, Indian, and Malay children in Singapore, ${ }^{31}$ other evidence has suggested that African-American infants are less prone to severe outcome ROP than white infants ${ }^{59}$ and Alaskan natives develop threshold ROP earlier than non-natives. ${ }^{60}$ This racial variation suggests that genetic, socioeconomic, ${ }^{59}$ or dietary ${ }^{60}$ factors may be involved.

The ocular features of acute ROP such as retinal folds, retinal traction, and retinal detachment show considerable morphological similarity with the rare familial disorders Norrie disease and familial exudative vitreoretinopathy (FEVR). Norrie disease is a bilateral $\mathrm{X}$ linked disorder characterised by ocular findings resembling acute ROP, and sometimes accompanied by intellectual disability and sensorineural deafness. ${ }^{61}$ Studies have shown a number of mutations in the Norrie disease gene associated with this disease, ${ }^{62-64}$ with the majority of mutations occurring in the translated region of the third exon.

While many of the retinal findings associated with FEVR are morphologically similar to those observed in advanced ROP, FEVR patients typically have a normal gestational period and lack a history of low birth weight or exposure to supplemental oxygen. In contrast with Norrie disease and ROP, FEVR tends to be a slowly progressive disorder with retinal detachment often not occurring until the first or second decade of life. ${ }^{65}$ FEVR may be inherited as an autosomal dominant, ${ }^{65}$ autosomal recessive, ${ }^{66}$ or $\mathrm{X}$ linked trait. ${ }^{67}$ Mutations in the Norrie disease gene have been shown to be present in patients with the X linked form of FEVR, ${ }^{68-71}$ suggesting that X linked FEVR and Norrie disease are allelic.

Given the similar ocular manifestations of ROP, Norrie disease and FEVR, the Norrie disease gene was an obvious candidate for investigation in ROP. However, studies of the contribution of this gene to ROP onset and progression remain inconclusive. Shastry et $a l^{72}$ found that of 12 children with severe ROP, four patients-including twins assumed to be monozygotic - had missense mutations R121W or L108P in the third exon of the Norrie disease gene. Another recent publication by Shastry's group ${ }^{73}$ reported an insertion and a deletion in the CT repeat region of exon 1 of the Norrie disease gene in two of 100 advanced ROP cases. Buffenn et al ${ }^{74}$ screened 12 premature African-American infants, and found a mutation in the $3^{\prime}$ untranslated region in one of the four cases with severe ROP. Hiraoka et $a l^{73}$ concluded that overall, Norrie disease mutations are associated with 3\% of cases of advanced ROP.

The fact that most epidemiological studies of ROP do not find a sex imbalance ${ }^{28313275}$ also suggests only a small proportion of severe ROP cases are likely to harbour Norrie disease gene mutations. Although interestingly, two studies have reported a skewed sex ratio in ROP, with twice the number of male infants affected.$^{7677}$ Reports do exist of females in Norrie disease and FEVR families displaying retinal abnormalities, ${ }^{78}{ }^{79}$ and Mintz-Hittner et $a l^{79}$ suggest that transplacental effects of maternal norrin may also be important. It is possible that mutations that would normally not be expressed in a full term infant may manifest in both males and females under conditions of prematurity. ${ }^{72}$ 
Haider et $a l^{80}$ screened a cohort of Kuwaiti premature newborns for the mutations identified by Shastry et $a l^{72}$ and two FEVR mutations (A105T and V60E) ${ }^{81}$ While the L108P, Al05T, and V60E mutations were detected in their population, Haider et al concluded that none of these mutations showed an association with advanced ROP ${ }^{80}{ }^{81}$ These results cast doubt on the Norrie disease gene's putative role in severe ROP, and suggest that population differences and choice of controls may also be critical in evaluating this gene's contribution.

Efforts to confirm the role of the Norrie disease gene and identify other genes contributing to ROP are confounded by the difficulty of clinically distinguishing between Norrie disease, FEVR and ROP in premature infants. It is conceivable, for example, that sporadic cases of Norrie disease or FEVR may be misdiagnosed as ROP if patients experience premature delivery.

Given that ROP is clearly non-Mendelian and that Norrie disease gene mutations have only been detected a small percentage of severe ROP cases, it is possible that other genetic factors modify the disease. Two loci-EVR1 ${ }^{82}$ and EVR3 ${ }^{83}-$ have been reported for the autosomal dominant form of FEVR and it is possible that once the genes at these loci are identified, they may also be found to have a role in $\mathrm{ROP}^{83}$

\section{Other putative risk factors}

Infants conceived through fertility programmes have a higher incidence of multiple births and subsequently premature deliveries, ${ }^{77} 8485$ raising the risk of ROP. Infants conceived by in vitro fertilisation account for the majority of the increased risk for this group ${ }^{86} \mathrm{~A}$ second at-risk group includes those infants with cerebral palsy who have a higher incidence of retinal vascular anomalies associated with both cerebral ischaemia and prematurity. ${ }^{87}$

A number of other risk factors have been suggested as contributors to ROP although it is unclear whether these are truly independent risk factors or simply indicators of the compromised health of the neonate. ${ }^{33}$ These factors include bronchopulmonary dysplasia, ${ }^{75}$ number of blood transfusions, ${ }^{75} 88$ parenteral nutrition, ${ }^{89}$ hypo/hypercarbia, ${ }^{89}$ early intubation, hypotension, patent ductus arteriosus, necrotising enterocolitis, ${ }^{32}$ administration of $\beta$ blockers to mothers before delivery, ${ }^{90}$ intraventricular haemorrhage, poor postnatal weight gain, ${ }^{88}$ and Candida sepsis. ${ }^{91}{ }^{92}$

No relation exists between ROP and maternal smoking, maternal alcohol intake, ${ }^{32}$ or exposure of the retina to light. ${ }^{93}$ Prenatal care does not affect the incidence or severity of $\mathrm{ROP}^{92}$ although the importance of reducing the incidence of premature delivery is emphasised. ${ }^{15}{ }^{31} 77$ Surprisingly, maternal pre-eclampsia may lead to a more favourable outcome for premature infants, ${ }^{33}$ perhaps because hypertension causes intrauterine stress and subsequent maturation of the eyes. ${ }^{94}$

\section{INCREASING INCIDENCE IN DEVELOPING COUNTRIES?}

A current concern is that a third epidemic of ROP may be emerging. In Sri Lanka ${ }^{95}$ and Lithuania ${ }^{76}$ the first reports of ROP have only recently been documented, although in Lithuania the mean birth weight and gestational age of infants who develop ROP have decreased quickly with improved facilities. ${ }^{76}$ In Thailand and the Philippines, ROP is not reported in rural areas but causes 15\% of visual loss in the cities where better medical facilities are available. ${ }^{12}$ It is predicted that as the survival of increasingly premature infants improves in developing countries, the overall numbers of children with ROP will increase. ${ }^{1095}$

\section{CONCLUSION}

Although ROP has been recognised as an important cause of blindness in developed countries for some years, it is now becoming more significant in developing countries. ${ }^{10}$ The
World Health Organization's Vision 2020 programme $^{8}$ targets ROP as an "avoidable disease" requiring early detection and treatment to prevent blindness and the inherent costs to the individual and the community. As described by Vision 2020, ${ }^{8}$ recent research has resulted in strategies that have been successful in reducing the incidence of ROP such as routine fundus examination of premature neonates less than 32 weeks' gestation or under $1250 \mathrm{~g}$, provision of carefully monitored levels of supplemental oxygen where necessary, and treatment and care by well trained and well equipped ophthalmologists. As a lower cost option for developing countries, screening only infants under $1200 \mathrm{~g}$ may be more cost effective. ${ }^{96}$ Current treatment options are expensive and can have potentially serious complications ${ }^{97}$; thus prevention is still the best strategy available at present to avoid blindness caused by ROP. For ROP to become a truly "avoidable" disease, further research is required to elucidate the underlying causes of ROP, enable prediction of the course of the disease, and propose new prevention strategies. It will be especially important to evaluate whether genetic factors do influence the outcome of ROP and whether novel drug therapies arising from this knowledge will result in better treatments, since even the best centres are unable to prevent blindness in a proportion of cases. However, in the short term, improved surveillance and treatment programmes are likely to be most effective in reducing blindness caused by ROP in developing countries.

\section{Authors' affiliations}

C M Wheatley, Discipline of Biochemistry, University of Tasmania, Hobart, Tasmania, Australia

J L Dickinson, M M Sale, Menzies Centre for Population Health Research, University of Tasmania, Hobart, Tasmania, Australia

D A Mackey, J E Craig, Centre for Eye Research Australia, University of Melbourne, Melbourne, Australia

\section{REFERENCES}

1 Piccioni A, Lanners J, Goergen E. Early rehabilitation in retinopathy of prematurity children (0-4 years). Progress in retinopathy of prematurity. Proceedings of the international symposium on retinopathy of prematurity, 1997, Taormina, Italy. Amsterdam/New York: Kugler Publications, 1997.

2 Mets MB. Childhood blindness and visual loss: an assessment at two institutions including a "new" cause. Trans Am Ophthalmol Soc 1999:97:653-96.

3 Victorian Infant Collaborative Study Group. Eight-year outcome in infants with birth weight of 500 to 999 grams: Continuing regional study of 1979 and 1980 births. J Pediatr 1991;118:761-7.

4 Halsey CL, Collin MF, Anderson CL. Extremely low birth weight children and their peers: a comparison of preschool performance. Pediatrics 1993;91:807-11.

5 Tamai H, Majima A. Implications of the severity of retinopathy of prematurity on childhood development. Jpn J Ophthalmol 1996:40:371-6.

6 The International Committee for the Classification of the Late Stages of Retinopathy of Prematurity. An international classification of retinopathy of prematurity. II. The classification of retinal detachment. Arch Ophthalmol 1987; 105:906-12.

7 Thylefors B. A global initiative for the elimination of avoidable blindness. Am J Ophthalmol 1998:125:90-3.

8 Gilbert C, Foster A. Childhood blindness in the context of Vision 2020 - the right to sight. Bull World Health Organ 2001;79:227-32.

9 Steinkuller PG, Du L, Gilbert C, et al. Childhood blindness. J AAPOS 1999;3:26-32.

10 Gilbert C, Rahi J, Eckstein M, et al. Retinopathy of prematurity in middle-income countries. Lancet 1997;350:12-4.

11 Jacobson L, Fernell E, Broberger U, et al. Children with blindness due to retinopathy of prematurity: a population-based study. Perinatal data neurological and ophthalmological outcome. Dev Med Child Neurol 1998:40:155-9.

12 Gilbert C, Foster A. Causes of blindness in children attending four schools for the blind in Thailand and the Philippines. A comparison between urban and rural blind school populations. Int Ophthalmol 1993:17:229-34.

13 Vyas J, Field D, Draper ES, et al. Severe retinopathy of prematurity and its association with different rates of survival in infants of less than 1251 $\mathrm{g}$ birth weight. Arch Dis Child Fetal Neonatal Ed 2000;82:F145-9.

14 Terry TL. Extreme prematurity and fibroplastic overgrowth of persistent vascular sheath behind each crystalline lens. Am J Ophthalmol 1942;25:203-4. 
15 Campbell K. Intensive oxygen therapy as a possible cause of retrolental fibroplasia: a clinical approach. MedJ Aust 1951;2:48-50.

16 Patz A, Hoeck LE, De La Cruz E. Studies on the effect of high oxygen administration in retrolental fibroplasia. I. Nursery observations. Am J Ophthalmol 1952:35:1248-52.

17 Ashton N, Ward B, Serpell G. Effect of oxygen on developing retinal vessels with particular reference to the problem of retrolental fibroplasia. Br J Ophthalmol 1954;38:397-430

18 Hatfield EM. Blindness in infants and young children. Sight Sav Rev 1972;42:69-89.

19 Avery ME, Oppenheimer EH. Recent increase in mortality from hyaline membrane disease. J Pediatr 1960;57:553-9

20 Phelps DL. Retinopathy of prematurity: an estimate of vision loss in the United States-1979. Pediatrics 1981;67:924-6.

21 Gibson DL, Sheps SB, Schechter MT, et al. Retinopathy of prematurity: a new epidemic? Pediatrics 1989:83:486-92.

22 Keith CG, Doyle LW, Kitchen WH, et al. Retinopathy of prematurity in infants of 24-30 weeks' gestational age. Med J Aust 1989;150:293-6.

23 Valentine PH, Jackson JC, Kalina RE, et al. Increased survival of low birth weight infants: impact on the incidence of retinopathy of prematurity. Pediatrics 1989:84:442-5.

24 Todd DA, Kennedy J, Roberts S, et al. Retinopathy of prematurity in infants less than 29 weeks' gestation at birth. Aust N Z J Ophthalmol 1994;22:19-23

25 Fledelius HC. Retinopathy of prematurity in a Danish county. Trends over the 12-year period 1982-93. Acta Ophthalmol Scand 1996;74:285-7

26 Todd DA, Kennedy J, Cassell C, et al. Retinopathy of prematurity in infants $<29$ weeks' gestation at birth in New South Wales from 1986-92. J Paediatr Child Health 1998;34:32-6.

27 Bullard SR, Donahue SP, Feman SS, et al. The decreasing incidence and severity of retinopathy of prematurity. J AAPOS 1999;3:46-52

28 Hussain N, Clive J, Bhandari V. Current incidence of retinopathy of prematurity, 1989-1997. Pediatrics 1999;104:e26

29 Rowlands E, lonides AC, Chinn S, et al. Reduced incidence of retinopathy of prematurity. Br J Ophthalmol 2001;85:933-5.

30 Todd DA, Cassell C, Kennedy J, et al. Retinopathy of prematurity in infants <32 weeks' gestation at birth in New South Wales in 1993 and 1994. J Paediatr Child Health 1999;35:355-7.

31 Leo SW, Cheong PYY. Incidence of retinopathy of prematurity in Singapore. Singapore Med J 1997;38:54-7.

32 Arrøe M, Peitersen B. Retinopathy of prematurity: review of a seven-year period in a Danish neonatal intensive care unit. Acta Paediat 1994;83:501-5

33 Seiberth V, Linderkamp O. Risk factors in retinopathy of prematurity. A multivariate statistical analysis. Ophthalmologica 2000;214:131-5.

34 Palmer EA. What have we learned about retinopathy of prematurity during the past ten years? Progress in retinopathy of prematurity. Proceedings of the international symposium on retinopathy of prematurity, 1997, Taormina, Italy. Amsterdam/New York: Kugler Publications, 1997.

35 Todd D, Kennedy J, Roberts V, et al. Risk factors in progression beyond stage 2 retinopathy of prematurity. Aust N Z J Ophthalmol 1990; 18:57-60

36 Coats DK, Paysse EA, Steinkuller PG. Threshold retinopathy of prematurity in neonates less than 25 weeks' estimated gestational age. $J$ AAPOS 2000;4: 183-5.

37 Flynn JT. The premature retina: a model for the in vivo study of molecular genetics? Eye 1992;6:161-5.

38 Kushner BJ, Essner D, Cohen IJ, et al. Retrolental fibroplasia. II. Pathologic correlation. Arch Ophthalmol 1977;95:29-38.

39 Chan-Ling T, Tout $\mathrm{S}$, Holländer $\mathrm{H}$, et al. Vascular changes and their mechanisms in the feline model of retinopathy of prematurity. Invest Ophthalmol Vis Sci 1992;33:2128-47.

40 Chan-Ling T, Gock B, Stone J. The effect of oxygen on vasoformative cell division. Evidence that 'physiological hypoxia' is the stimulus for normal retinal vasculogenesis. Invest Ophthalmol Vis $\mathrm{Sci}$ 1995;36:1201-14

41 McLeod DS, Brownstein R, Lutty GA. Vaso-obliteration in the canine model of oxygen-induced retinopathy. Invest Ophthalmol Vis Sci 1996:37:300-11.

42 The STOP-ROP Multicenter Study Group. Supplemental therapeutic oxygen for prethreshold retinopathy of prematurity (STOP-ROP), a randomized, controlled trial. I: Primary outcomes. Pediatrics 2000;105:295-310.

43 Cunningham S, Fleck BW, Elton RA, et al. Transcutaneous oxygen levels in retinopathy of prematurity. Lancet 1995;346:1464-5.

44 Penn JS, Henry MM, Tolman BL. Exposure to alternating hypoxia and hyperoxia causes severe proliferative retinopathy in the newborn rat. Pediatr Res 1994;36:724-31.

45 Chan-Ling T, Stone J. Retinopathy of prematurity: origins in the architecture of the retina. Progress in retinal research. Oxford: Pergamon Press, 1993:155-78

46 Katz ML, Robison WG Jr. Autoxidative damage to the retina: potential role in retinopathy of prematurity. Birth Defects Orig Artic Ser 1988;24:237-48.

47 Huertas JR, Palomino N, Ochoa JJ, et al. Lipid peroxidation and antioxidants in erythrocyte membranes of full-term and preterm newborns. Biofactors 1998;8:133-7.

48 Hittner HM, Godio LB, Speer ME, et al. Retrolental fibroplasia: furthe clinical evidence and ultrastructural support for efficacy of vitamin $E$ in the preterm infant. Pediatrics 1983;71:423-32.
49 Alon T. Hemo I, Itin A, et al. Vascular endothelial growth factor acts as a survival factor for newly formed retinal vessels and has implications for retinopathy of prematurity. Nat Med 1995;1:1024-8.

50 Robbins SG, Conaway JR, Ford BL, et al. Detection of vascular endothelial growth factor (VEGF) protein in vascular and non-vascular cells of the normal and oxygen-injured rat retina. Growth Factors 1997; 14:229-41.

51 Robbins SG, Rajaratnam VS, Penn JS. Evidence for upregulation and redistribution of vascular endothelial growth factor (VEGF) receptors flt-1 and flk-1 in the oxygen-injured rat retina. Growth Factors 1998;16:1-9.

52 Okamoto N Tobe T, Hackett SF, et al. Transgenic mice with increased expression of vascular endothelial growth factor in the retina: a new model of intraretinal and subretinal neovascularization. Am J Pathol 1997; 151:281-91

53 Tolentino MJ, Miller JW, Gragoudas ES, et al. Vascular endothelial growth factor is sufficient to produce iris neovascularization and neovascular glaucoma in a nonhuman primate. Arch Ophthalmol 1996:114:964-70.

54 Thieme $\mathbf{H}$, Aiello LP, Takagi $\mathrm{H}$, et al. Comparative analysis of vascular endothelial growth factor receptors on retinal and aortic vascular endothelial cells. Diabetes 1995:44:98-103.

55 Lashkari K, Hirose T, Yazdany J, et al. Vascular endothelial growth factor and hepatocyte growth factor levels are differentially elevated in patients with advanced retinopathy of prematurity. Am J Pathol 2000; 156:1337-44.

56 Hughes S, Yang H, Chan-Ling T. Vascularization of the human fetal retina: roles of vasculogenesis and angiogenesis. Invest Ophthalmol Vis Sci 2000;41:1217-28

57 Hellstrom A, Perruzzi C, Ju M, et al. Low IGF-I suppresses VEGF-survival signaling in retinal endothelial cells: direct correlation with clinical retinopathy of prematurity. Proc Natl Acad Sci USA 2001;98:5804-8.

58 Schaffer DB, Palmer EA, Plotsky DF, et al. Prognostic factors in the natural course of retinopathy of prematurity. Ophthalmology 1993; 100:230-7

59 Saunders RA, Donahue ML, Christmann LM, et al. Racial variation in retinopathy of prematurity. Arch Ophthalmol 1997;115:604-8.

60 Arnold RW, Kesler K, Avila E. Susceptibility to retinopathy of prematurity in Alaskan Natives. J Pediatr Ophthalmol Strabismus 1994;31:192-4.

61 Warburg M. Norrie's disease: a new hereditary bilateral pseudotumour of the retina. Acta Ophthalmol 1961;39:757-72.

62 Schuback DE, Chen ZY, Craig IW, et al. Mutations in the Norrie disease gene. Hum Mutat 1995;5:285-92.

63 Meindl A, Lorenz B, Achatz H, et al. Missense mutations in the NDP gene in patients with a less severe course of Norrie disease. Hum Mol Genet 1995;4:489-90

64 Ott S, Patel RJ, Appukuttan B, et al. A novel mutation in the Norrie disease gene. J AAPOS 2000;4:125-6.

65 Criswick VG, Schepens CL. Familial exudative vitreoretinopathy. Am J Ophthalmol 1969;68:578-94.

66 de Crecchio G, Simonelli F, Nunziata G, et al. Autosomal recessive familial exudative vitreoretinopathy: evidence for genetic heterogeneity. Clin Genet 1998;54:315-20.

67 Plager DA, Orgel IK, Ellis FD, et al. X-linked recessive familial exudative vitreoretinopathy. Am J Ophthalmol 1992;114:145-8.

68 Chen ZY, Battinelli EM, Fielder A, et al. A mutation in the Norrie disease gene (NDP) associated with X-linked familial exudative vitreoretinopathy. Nat Genet 1993:5:180-3.

69 Fuchs S, Kellner U, Wedemann H, et al. Missense mutation (Arg 121Trp) in the Norrie disease gene associated with X-linked exudative vitreoretinopathy. Hum Mutat 1995;6:257-9.

70 Shastry BS, Hejtmancik JF, Trese MT. Identification of novel missense mutations in the Norrie disease gene associated with one X-linked and four sporadic cases of familial exudative vitreoretinopathy. Hum Mutat 1997;9:396-401.

71 Shastry BS, Hiraoka M, Trese DC, et al. Norrie disease and exudative vitreoretinopathy in families with affected female carriers. Eur J Ophthalmol 1999;9:238-42.

72 Shastry BS, Pendergast SD, Hartzer MK, et al. Identification of missense mutations in the Norrie disease gene associated with advanced retinopathy of prematurity. Arch Ophthalmol 1997;1 15:651-5.

73 Hiraoka M, Berinstein DM, Trese MT, et al. Insertion and deletion mutations in the dinucleotide repeat region of the Norrie disease gene in patients with advanced retinopathy of prematurity. J Hum Genet 2001;46:178-81.

74 Buffenn AN, Bernstein SL, Hutcheson KA. Identification of a new Norrie disease gene mutation in an African-American infant with advanced retinopathy of prematurity. Invest Ophthalmol Vis Sci 1999;40:S565

75 Englert JA, Saunders RA, Purohit D, et al. The effect of anemia on retinopathy of prematurity in extremely low birth weight infants. $J$ Perinatol 2001;21:21-6.

76 Bagdoniene R, Sirtautiene R. Threshold retinopathy of prematurity in Lithuania: tendencies during three years. Progress in retinopathy of prematurity. Proceedings of the international symposium on retinopathy of prematurity; 1997, Taormina, Italy. Amsterdam/New York: Kugler Publications, 1997.

77 Nødgaard H, Andreasen $\mathrm{H}$, Hansen $\mathrm{H}$, et al. Risk factors associated with retinopathy of prematurity (ROP) in northern Jutland, Denmark 1990-1993. Acta Ophthalmol Scand 1996;74:306-10.

78 Sims KB, Irvine AR, Good WV. Norrie disease in a family with a manifesting female carrier. Arch Ophthalmol 1997;115:517-9.

79 Mintz-Hittner HA, Ferrell RE, Sims KB, et al. Peripheral retinopathy in offspring of carriers of Norrie disease gene mutations. Possible 
transplacental effect of abnormal Norrin. Ophthalmology 1996; 103:2128-34

80 Haider MZ, Devarajan LV, Al-Essa M, et al. Missense mutations in Norrie disease gene are not associated with advanced stages of retinopathy of prematurity in Kuwaiti Arabs. Biol Neonate 2000;77:88-91.

81 Haider MZ, Devarajan LV, Al-Essa M, et al. Retinopathy of prematurity: Mutations in the Norrie disease gene and the risk of progression to advanced stages. Pediatrics Int 2001;43:120-3.

82 Price SM, Periam N, Humphries A, et al. Familial exudative vitreoretinopathy linked to D1 1S533 in a large Asian family with consanguinity. Ophthalmic Genet 1996;17:53-7.

83 Downey LM, Keen TJ, Roberts E, et al. A new locus for autosomal dominant familial exudative vitreoretinopathy maps to chromosome $11 \mathrm{pl2-13.} \mathrm{Am} \mathrm{J} \mathrm{Hum} \mathrm{Genet} \mathrm{2001;68:778-81.}$

84 McKibbin M, Dabbs TR. Assisted conception and retinopathy of prematurity. Eye 1996;10:476-8.

85 Bergh T, Ericson A, Hillensjö T, et al. Deliveries and children born after in-vitro fertilisation in Sweden 1982-95: a retrospective cohort study. Lancet 1999;354:1579-85.

86 Watts P, Adams GG. In vitro fertilisation and stage 3 retinopathy of prematurity. Eye 2000;14:330-3.

87 Pennefather PM, Tin W. Ocular abnormalities associated with cerebral palsy after preterm birth. Eye 2000;14:78-81.

88 Wallace DK, Kylstra JA, Phillips SJ, et al. Poor postnatal weight gain: a risk factor for severe retinopathy of prematurity. J AAPOS 2000;4:343-7
89 Shohat M, Reisner SH, Krikler R, et al. Retinopathy of prematurity: incidence and risk factors. Pediatrics 1983;72:159-63.

90 Ben Sira I, Nissenkorn I, Kremer I. Retinopathy of prematurity. Surv Ophthalmol 1988;33:1-16

91 Karlowicz MG, Giannone PJ, Pestian J, et al. Does candidemia predict threshold retinopathy of prematurity in extremely low birth weight $(</=1000 \mathrm{~g})$ neonates? Pediatrics 2000;105:1036-40.

92 Higgins RD, Mittal M, Dhanireddy R. Retinopathy of prematurity at an urban center: association with Candida sepsis. Progress in retinopathy of prematurity. Proceedings of the international symposium on retinopathy of prematurity, 1997; Taormina, Italy. Amsterdam/New York: Kugler Publications, 1997.

93 Reynolds JD, Hardy RJ, Kennedy KA, et al. Lack of efficacy of light reduction in preventing retinopathy of prematurity. Light Reduction in Retinopathy of Prematurity (LIGHT-ROP) Cooperative Group. N Engl J Med 1998:338:1572-6.

94 Hadi HA, Hobbs CL. Effect of chronic intrauterine stress on the disappearance of tunica vasculosa lentis of the fetal eye: a neonatal observation. Am J Perinatol 1990;7:23-5

95 Weerakoon IK, Fonseka C. Retinopathy of prematurity in Sri Lanka. Ceylon Med J 1998;43:194-5

96 Lee SK, Normand C, McMillan D, et al. Evidence for changing guidelines for routine screening for retinopathy of prematurity. Arch Pediatr Adolesc Med 2001;155:387-95.

97 Whitfill CR, Drack AV. Avoidance and treatment of retinopathy of prematurity. Sem Pediatr Surg 2000;9:103-5.

\section{Call for peer reviewers}

Clinical Evidence is a regularly updated evidence based journal available world wide both as a paper version and on the internet. Clinical Evidence urgently needs to recruit a number of new contributors. Contributors are health care professionals or epidemiologists with experience in evidence based medicine and the ability to write in a concise and structured way.

Clinical Evidence needs to recruit a number of new peer reviewers. Peer reviewers are health care professionals or epidemiologists with experience in evidence based medicine. As a peer reviewer you would be asked for your views on the clinical relevance, validity and accessibility of specific topics within the journal, and their usefulness to the intended audience (international generalists and health care professionals, possibly with limited statistical knowledge). Topics are usually 2000-3000 words in length and we would ask you to review between 2-5 topics per year. The peer review process takes place throughout the year, and our turnaround time for each review is ideally 10-14 days.

If you are interested in becoming a peer reviewer for Clinical Evidence, please complete the peer review questionnaire at www.clinicalevidence.com or contact Polly Brown (pbrown@bmigroup.com). 